\title{
PEMANFAATAN LIMBAH CINCAU HITAM MENJADI PUPUK ORGANIK PADAT PADA KELOMPOK WANITA TANI DESA NAMBAAN KABUPATEN KEDIRI
}

\author{
Samudi, Lina Saptaria \\ Universitas Islam Kadiri Kediri \\ email: samudimbah moed@yahoo.co.id; linauniskakediri@gmail.com
}

\begin{abstract}
ABSTRAK
Pertanian modern bersifat monokultur ( seragam) berskala besar yang ekstensif dan tergantung pada asupan kimia yang sangat tinggi serta mekanisasi intensif menyebabkan serangkaian dampak negatif terhadap kesehatan dan lingkungan Wan Ho, ddk. (2002). Revolusi hijau dengan asumsi yang mendasarkan pada pertumbuhan itu ternyata salah. Pertumbuhan produksi yang berhasil dicapai tidak mampu mengangkat kesejahteraan petani. Revolusi hijau justru meminggirkan petani. Petani menjadi tergantung pada perusahaan-perusahaan besar untuk menjalankan usaha pertanian mereka. Selain memarjinalkan petani revolusi hijau juga membawa dampak kerusakan yang luas terhadap lingkungan. Tanah persawahan semakin lama menjadi semakin keras dan bantatL untuk memulihkan kembali kosidi tanah yang keras dan bantat tersebut, perlu adanya penambahan bahan organik dari limbah-limbah pertanian. Limbah industri pengolahan cincau hitam UD RSA Kota Kediri dapat digunakan menjadi bahan baku pembuatan pupuk organik padat.. Pupuk organik padat dengan bahan baku utama sisa-sisa tanaman dapat dilakukan dengan sistem pengomposan. Proses pengomposan limbah cincau hitam dilaksanakan di rumah kompos Kelompok Wanita Tani Desa Nambaan. Penelitian ini bertujuan untuk mengetahui kandungan unsur hara yang terdapat dalam limbah cincau hitam berdasarkan sifat fisik, kimia dan biologis. Metodologi penelitian menggunakan metode ekperimen/percobaan sederhana dengan sistem dekomposisi anaerob menggunakan aktivator efektif mikro organisme 4. Hasil penelitian menunjukkan pembuatan pupuk organik padat limbah cicau hitam yang diproses secara an aerob dengan menggunakan dekomposer an aerob didapatkan hasil analisa uji kandungan unsur hara sebagai berikut : $p H$ 9,72, NPK dalam prosentase 0,57:1,19:2,16, sedangkan hara mikro Fe:Mn:Cu:Zn dengan perbandingan dalam ppm 5023:283:41:54, C-Organik 5,69 dan CN ratio 10. Standar Mutu Produksi berdasarkan PP Nomor 70 Tahun 2011 tentang pupuk organik, pupuk organik padat limbah cincau hitam dapat digunakan sebagai pembangun kesuburan tanah.
\end{abstract}

Kata Kunci : Limbah cincau hitam, pupuk organik padat, dekomposisi anaerob, Kelompok Tani Wanita, Unsur hara mikro dan makro.

\section{PENDAHULUAN}

Pertanian modern bersifat monokultur (seragam) berskala besar yang ekstensif dan tergantung pada asupan kimia yang sangat tinggi serta mekanisasi intensif menyebabkan serangkaian dampak negatif terhadap kesehatan dan lingkungan Wan Ho, ddk. (2002). Revolusi hijau dengan asumsi yang mendasarkan pada pertumbuhan itu ternyata salah. Pertumbuhan produksi yang berhasil dicapai tidak mampu mengangkat kesejahteraan petani. Revolusi hijau justru meminggirkan petani. Petani menjadi tergantung pada perusahaan-perusahaan besar untuk menjalankan usaha pertanian mereka. Selain memarjinalkan petani revolusi hijau juga membawa dampak kerusakan yang luas terhadap lingkungan. Tanah persawahan semakin lama menjadi semakin keras dan bantat. Penggunaan pupuk kimia meningkat dari waktu kewaktu. Serangan hama menjadi semakin eksplosif dan menuntut penggunaan pestisida yang semakin meningkat pula.
Pestisida tidak hanya mematikan hama tanaman tetapi juga memusnahkan banyak kehidupan yang lain. Dunia Barat, sebagai penggagas pertanian modern sudah lama menyadari dampak yang ditimbulkan dari penggunaan bahan-bahan kimia sintetis dalam dunia pertanian. Masih banyak petani Indonesia yang menerapkan sistem tanam konvensional dengan kebiasaan menggunakan pestisida dalam jumlah besar dan frekuensi pemberian pestisida yang terus menerus. Hal ini berdampak buruk bagi kesuburan tanah dan kesehatan masyarakat, oleh karena itu, sistem pertanian harus dirubah menjadi sistem yang ramah lingkungan dan menjamin kesehatan masyarakat. Solusi yang dicanangkan oleh pemerintah untuk menangani masalah ini adalah menggalakkan seribu desa dengan sistem tanam pertanian organik. Sistem pertanian organik adalah suatu sistem manajemen produksi yang holistik (menyeluruh) untuk meningkatkan dan mengembangkan kesehatan agroekosistem, 
termasuk keragaman hayati, siklus biologi, dan aktivitas biologi tanah. Pertanian organik menekankan penerapan praktik-praktik manajemen yang lebih mengutamakan penggunaan input dari limbah kegiatan budidaya di lahan dengan mempertimbangkan daya adaptasi terhadap keadaan atau kondisi setempat. Jika memungkinkan hal tersebut dapat dicapai dengan menggunakan budaya, metode biologi, dan mekanik, yang tidak menggunakan bahan sintesis untuk memenuhi kebutuhan khusus dalam sistem (Kardinan, 2016).

Solusi dari proses pertanian konvesional diatas adalah uapay mengembalikan tingkat kesuburan tanah dengan menggunakan bahan organik serta penggunaan pupuk organik $50 \%$ dari penggunaan pupuk kimia sintetis. Selain memperbaiki sifat fisik maupun biologis, secar perlahan pupuk organik akan ampu menyediakan unsur kimia dalam tanah walaupun denga jumlah yang terbatas. Pemakaian baha $\mathrm{n}$ organik yang tinggi diharapkan mampu mengembalikan daya dukung lahan pertanian. Alah satu sumber bahan organik yang tinggi khususnya dikotakediri adalah pabrik pengolahan cincau hitam. Dimana limbah cincau padat ini sekiranya mampu digunakan sebagai pupuk organik melalui poses dekomposisi bahan organik.

Limbah industri yang dihasilkan oleh UD RSA Kota Kediri dapat dimanfaatkan sebagai bahan baku pembuatan pupuk organik. Kendala yang dihadapi oleh UD RSA dalam menangani limbah industrinya selama ini adalah belum adanya tenaga Sumber Daya Manusia yang mampu menangani dan mengelola limbah yang dihasilkan secara berkelanjutan.

Industri pupuk organik di Indonesia sangat prospektif untuk dikembangkan karena semakin meningkatnya permintaan produk organik. Masyarakat mengenal produk organik sebagai makanan sehat yang aman dikonsumsi dan ramah lingkungan. Permintaan pupuk organik di wilayah Kota dan Kabupaten Kediri Tahun 2017 cukup besar mencapai 4.652.461 ton. Sehingga perlu adanya upaya bagaimana memanfaatkan limbah cincau hitam menjadi pupuk organik.

Pembuatan pupuk organik/kompos limbah cincau hitam, perlu melakukan penelitian untuk mengetahui kandungan unsur hara yang terdapat dalam limbah cincau berdasarkan PP no 70 tahun 2011 tentang pupuk organik. Kegiatan penelitian ini meliputi aspek teknis baik proses, uji laboratorium terhadap kandungan unsur hara termasuk sifat fisik, kimia dan biologis pupuk, sehingga memenuhi kriteria berdasarkan peraturan tersebut.

\section{METODE PENELITIAN}

Penelitian ini dilaksanakan di KWT Desa Nambaan yang berlokasi di Desa Nambaan Kecamatan Ngasem Kabupaten Kediri Jawa Timur. Pemilihan tempat dilakukan secara sengaja (purposive) berdasarkan pertimbangan bahwa lokasi ini merupakan tempat proses produksi pupuk organik yang akan didirikan. pembuatan pupuk organik padat limbah cincau berbahan baku utama limbah cincau hitam dan bahan penolong kohe sapi dan kambing serta bahan pembantu berupa kalcium dan abu/arang sekam. Metode pembuatan dengan ekperimen sederhana menggunakan dekomposisi anaerob dengan menggunakan ekfektif mikro organisme. .Pelaksanaan penelitian dan pengambilan data dilakukan pada bulan Maret hingga Juli 2018. Data yang dikumpulkan berupa data primer dan data sekunder. Data primer diperoleh melalui analisis uji laboratorium tentang kandungan unsur hara termasuk sifat fisik, kimia dan biologis pupuk. Data sekunder diperoleh melalui studi literatur berbagai buku, jurnal, skripsi, dan artikel yang terkait dengan topik penelitian. Metode observasi berarti peneliti melakukan pengamatan langsung mengenai seluruh proses kegiatan pembuatan pupuk organik mulai dari input, proses transformasi, dan output. Data kuantitatif yang diperoleh selama penelitian diolah dengan menggunakan program Microsoft Excel 2007. Sedangkan data kualitatif diperoleh dari hasil uji laboratorium. Proses Pembuatan pupuk organik digambarkan dalam diagram berikut ini.

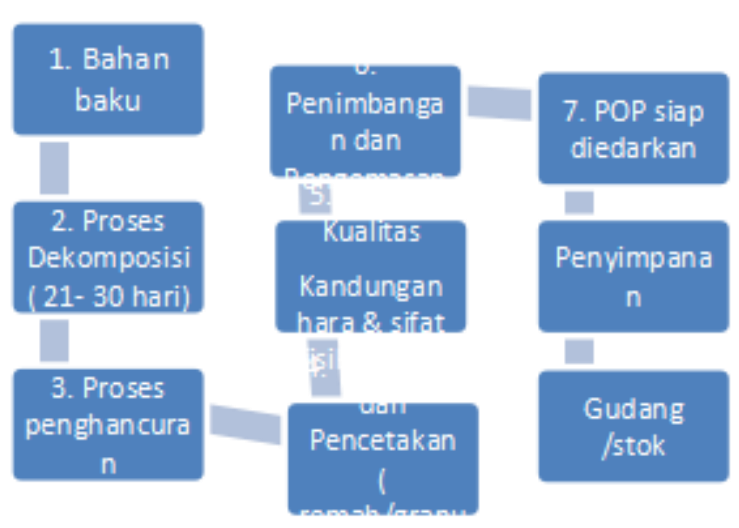

Gambar 1. Alur Proses Pembuatan Pupuk Organik Padat Limbah Cincau Hitam 
Kerangan gambar :

1) Tahap pertama, pengumpulan bahan baku utama dan bahan penolong.

2) Tahap kedua, proses dekomposisi an aerob bakteri/dekomposer/aktivator. dengan

3) Tahap ketiga, menghancurkan ukuran pupuk menjadi remah.

4) Tahap keempat,sterilisasi atau membuat bentuk ( serbuk halus dan atau granul).

5) Tahap kelima, kontrol kualitas dengan uji laboratorium dan uji efektivitas/uji lapangan

6) Tahap keenam, penimbangan sekaligus pengemasan sesuai dengan permintaan atau kemasan ( $5 \mathrm{~kg}$ ataupun $40 \mathrm{~kg}$ ).

7) Tahap ketujuh, Penyimpanan atau pergudangan, dimana pupuk disimpan ataupun siap diedarkan kepada anggota kelompoktani.

\section{HASIL DAN PEMBAHASAN}

\section{A. Karakteristik Limbah Padat Cincau Hitam}

Berdasarkan hasil studi pustaka, limbah daun cincau hitam dapat digunakan sebagai bahan baku pembuatan pupuk organik, dimana terdapat kandungan fosfor, kalsium dan zat besi serta nisbah $\mathrm{CN}$ ratio yang rendah sehingga dapat dijadikan bahan baku pembuatan pupuk organik padat yang singkat. Proses pembuatan pupuk organik padat akan optimal apabila bahan baku mempunyai nisbah $\mathrm{CN}$ ratio 25 sampai 40 (Suwahyono, 2015). Faktor lain adalah ukuran partikel, aerasi, porositas, kelembaban, suhu, $\mathrm{pH}$, kandungan hara dan kandungan bahan berbahaya. Ukuran partikel menentukan besarnya ruang antar bahan ( porositas) . permukaan yang luas akan meningkatkan kontak antara mikroba dengan bahan sehingga dekomosisi akan berjalan lebih cepat. Aerasi secara alami akan terjadi secara alami akan terjadi pada saat peningkatan suhuyang menyebabka udara hangat keluar dan sebaliknya. Apabila aerasi terhambat, maka akan terjadi proses anaeob sehingga muncul bau yang tidak sedap. Porositas adalah ruang di antara partikel di dalam tumpukan pupuk organik. Porositas ini dihitung dengan mengukur volume rongga dibagi volume total. Rongga -rongga ini yang akan diisi air dan udara selama proses dekomposisi. Kelembaban memegang peranan penting dalam proses metabolisme mikroba dan secara tidak langsung berbengaruh pada ketersediaan oksigen. Suhu yang tinggi akan berpengaruhi terhadap konsumsi oksigen oleh mikroba sehingga akan semakin cepat proses dekomposisi. pH yang optimal dalam proses dekomposisi pada kisaran 6.5 samapai 7.5. proses dekomposisi akan menyebabkan penurunan $\mathrm{pH}$ sedangkan produksi amonia dari senyawa yang mengandung nitrogen akan meningkatkan $\mathrm{pH}$, sehingga dekomposisi yang sempurna akan mendekati $\mathrm{pH}$ netral. Kandungan hara $\mathrm{P}$ dan $\mathrm{K}$ juga penting dalam proses pembuatan pupuk organik padat hara ini akan dimanfaatkan oleh mikroba selama proses dekomposisi sedangkan kandungan bahan berbahaya seperti logam-logam berat $\mathrm{Mg}, \mathrm{Cu}, \mathrm{Zn}$, Nickel $\mathrm{Cr}$ akan mengalami imobilisasi selama proses dekomposisi ( Dermiyati, 2015).

\section{B. Kualitas Pupuk Organik Padat}

Berdasarkan hasil pengolahan limbah cincau hitam menjadi pupuk organik padat selama satu bulan, didapatkan hasil analisa kandungan unsur hara dari pupuk organik padat yang disajikan pada tabel 1 .

Tabel 1. Kandungan Unsur Hara Pupuk Organik Padat

No. Paramete Kandungan Kandungan

\begin{tabular}{llll} 
& $r$ & dalam $(\%)$ & dalam angka \\
\hline 1. & Nitrogen & 0,57 & \\
\hline
\end{tabular}

\begin{tabular}{lll}
\hline 2. & $\mathrm{P}_{2} \mathrm{O}_{5}$ & 1,19 \\
\hline 3. & $\mathrm{~K}_{2} \mathrm{O}$ & 2,16
\end{tabular}

4. $\quad$ C-Organik 5,69

5. CN Ratio 10

6. $\mathrm{Fe} \quad 5023 \mathrm{ppm}$

7. $\mathrm{Mn} 2283 \mathrm{ppm}$

\begin{tabular}{lll}
\hline 8. & $\mathrm{Cu}$ & $41 \mathrm{ppm}$ \\
\hline 9. & $\mathrm{Zn}$ & $54 \mathrm{ppm}$
\end{tabular}

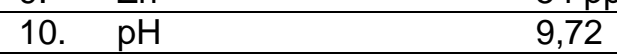

11. Kadar air 41,71

Sumber:Laporan Hasil Pengujian Puslit Gula ptpn x, 2018

Berdasarkan Tabel 1 dapat diketahui kandungan pupuk organik padat yang dihasilkan. Ditinjau dari sifat kimia, pupuk organik mempunyai kondisi $\mathrm{pH}$ 9,72. $\mathrm{pH}$ sangat menentukan mudah tidahnya unsur hara diserap oleh tanaman. Pada umumnya tanaman mampu menyerap unsur hara pada $\mathrm{pH}$ netral hingga basa, karena pada $\mathrm{pH}$ tersebut unsur hara dapat larut dala air. Nisbah $\mathrm{CN}$ ratio 10 tergolong rendah sehingga mudah mengalami dekomposisi sehingga dapat meningkatkan kandungan bahan organik maupun C-organik tanah yang dapat meningkatkan sifat fisik dsan biologi tanah. sedangkan unsur hara makro NPK yang terdapat dalam pupuk organik padat didapatkan perbandingan 0,57:1,19:2,16 tergolong rendah, namun unsur hara ini sangat penting bagi pertumbuhan tanaman. Apabila 
tanaman terjadi defisiensi hara akan berpengaruh dalam proses pertumbuhannya. Nitrogen $(\mathrm{N})$ berfungsi memacu pertumbuhan tanaman secara umum, terutama pada fase vegetatif, berperan dalam pembentukan klorofil, asam amino, lemak, enzim, dan persenyawaan lain. Gejala tanaman yang membutuhkan pupuk $\mathrm{N}$ pertumbuhan tanaman lambat. Mula-mula daun menguning dan mengering, lalu rontok. Daum yg menguning diawali dari daun bagian bawah, lalu disusul daun bagian atas. Pupuk Posfor $\left(\mathrm{P}_{2} \mathrm{O}_{5}\right)$ memacu pertumbuhan protein dan miniral yg sangat tinggi bagi tanaman. Bertugas mengedarkan energi keseluruh bagian tanaman. Merangsang pertumbuhan dan perkembangan akar. Mempercepat pembungaan dan pembuahan tanaman. Serta mempercepat pemasakan biji dan buah. Gejala tanaman yang membutuhkan pupuk ini adalah daun bawah berubah warna menjadi tua atau tampak mengkilap merah keunguan. Kemudian menjadi kuning keabuan dan rontok. Tepi daun, cabang, dan batang berwarna merah keunguan. Batang kerdil dan tidak menghasilkan bunga dan buah. Jika sudah terlanjur berbuah ukurannya kecil, jelek, dan lekas matang. Kalium $\left(\mathrm{K}_{2} \mathrm{O}\right)$ Membantu pembentukan protein, karbohidrat dan gula. Membantu pengankutan gula dari daun ke buah. Memperkuat jaringan tanaman, serta meningkatkan daya tahan terhadap penyakit. Gejala tanaman yang membutuhkan pupuk ini adalah daun mengkerut atau keriting, timbul bercak-bercak merah kecoklatan lalu kering dan mati. Perkembangan kar lambat. Buah tumbuh tidak sempurna, kecil, jelek, dan tidak tahan lama. Sedangkan unsur hara mikro Fe:Mn:Cu:Zn didapatkan perbandingan 5023:283:41:54. Untuk kandungan zat besi (Fe) cukup tinggi sehingga pupuk mampu berperan pada proses-proses fisiologis tanaman, seperti proses pernapasan, pembentukan klorofil dan fotosintesis. Gejala tanaman yang membutuhkan pupuk ini adalah aun muda berwarna putih pucat lalu kekuningan, dan akhirnya rontok. Tanaman perlahan-lahan mati dimuali dari puncak. Unsur Mangan ( $\mathrm{Mn}$ ) Membantu proses fotosintesis, dan berperan dalam pembentukan enzim-enzim tanaman. Gejala tanaman yang membutuhkan pupuk ini Pertumbuhan tanaman kerdil, daun berwarna kekuningan atau merah dan sering rontok. Pembentukan biji tidak sempurna. Tembaga ( $\mathrm{Cu}$ ) Membantu pembentukan klorofil dan sebagai komponen dalam pembentukan enzim tanaman. Gejala tanaman yang membutuhkan pupuk ini daun muda berwarna kuning layu dan tidak berkembang. pertumbuhan dan kesuuran tanaman terhambat secara keseluruhan. Dan unsur Seng ( $\mathrm{Zn}$ ) Mmebantu pembentukan auksin, klorofil, dan karbohidrat. Gejala tanaman yang membutuhkan pupuk ini daun berwarna kuning pucat atau kemerahan, muncul bercak-bercak putih di permukaan daun hingga akhirnya mengering, berlubang dan mati. Perkembangan akar tidak sempurna, sehingga pendek dan tidak subur (Mulyono, 2016).

\section{Manfaat}

Berbagai hasil penelitian mengindikasikan bahwa sebagian besar lahan pertanian intensif muenurun produktifitasnya dan telah mengalami degradasi lahan, terutama terkait dengan sangat rendahnya kandungan karbon organik dalam tanah $1 \%$. Padahal untuk emndapatkan produktivitas yang ideal dibutuhkan karbon organik sekitar $5 \%$. Pupuk organik padat ini sangat bermafaat bagi peningkatan produksi pertanian baik kualitasa dan kuantitas, mengurangi pencemaran lingkungan dan meningkatkan kualitas lahan secara berkelanjutan. Pupuk organik dapat perperan sebagai pengikat butiran primer menjadi butiran sekunder tanah dalam pembentukan pupuk. Keadaan ini mempengaruhi penyimpanan, penyediaan air, aerasi tanah, dan suhu tanah. pupuk organik memiliki fungsi kimia yang penting seperti ( Budiman, 2015):

Penyedia hara makro ( nitrogen, fosfor, kalium, kalsium, magnesium, dan sulfur) dan mikro seperti zink, tembaga, kobalt, barium, mangan dan besi, meskipun jumlahnya relatif sedikit.

- Meningkatkan kapasitas tukar kation ( KTK) tanah .

\section{KESIMPULAN DAN SARAN}

1. Pupuk organik padat dari limbah cincau hitam di dapatkan nilai perbandingan NPK 0,57:1,19:2,16 masih cukup rendah sehingga dalam aplikasi terhadap tanaman perlu adanya upaya penambahan sumber NPK yang lain.

2. Hasil analisa secara keseluruhan menunjukkan bahwa pupuk organik padat limbah cincau hitam belum dapat digolongkan sebagai pupuk organik tetapi dapat dijadikan sebagai pembangun kesuburan tanah.

3. Untuk mempercepat proses pembuatan pupuk organik padat dari limbah cincau hitam sebaiknya menggunakan metode anaerob dan mikroba an-aerob.

\section{DAFTAR PUSTAKA}

Bargumono,2002.Pertanian Organik Solusi Alternatif Pertanian:Global Pustaka 
Utama.Yogyakarta.

Budiman, Haryanto.2015. Budidaya Jagung Organik. Pustaka Baru Press. Yogyakarta.

Dermiyati, 2015. Sistem Pertanian Organik Berkelanjutan.Plantaxia. Yogyakarta.

Hadisuwito, Sukamto. 2008. Membuat Pupuk Kompos Cair:Agromedia Pustaka.Jakarta.

Mulyono, 2016. Membuat Mikro Organisme Lokal ( MOL) dan Kompos Dari Sampah Rumah Tangga. PT. Agromedia Pustaka. Jakarta

Kardinan, Agus, 2016. Sistem Pertanian Organik (Falsafah, Prinsip Inspeksi):Intimedia. Malang.

Wan Ho dan Li Ching, 2006. Gerakan Menuju Dunia Berkelanjutan Bebas Dari Rekayasa Genetik. Konphalindo. Jakarta.
Sutanto, Rachman. 2002. Pertanian Organik ( Menuju Pertanian Alternatif dan Berkelanjutan): Kanisius.Yogyakarta.

Suwahyono, Untung. 2015. Cara Cepat Buat Kompos. Penebar Swadaya. Jakarta.

Yuliarti, Nurheti. 2009. 1001 Cara Menghasilkan Pupuk Organik: Publisher.Yogyakarta. 